\title{
Drivers and Barriers of Sustainability Reporting in the Greek Public Forest Service
}

\author{
Konstantinos G. Papaspyropoulos, Dimitrios Karamanolis \\ Laboratory of Forest Economics, Aristotle University of Thessaloniki, Thessaloniki, Greece \\ Email: kodafype@for.auth.gr
}

Received 17 June 2016; accepted 14 July 2016; published 18 July 2016

Copyright (C) 2016 by authors and Scientific Research Publishing Inc.

This work is licensed under the Creative Commons Attribution International License (CC BY). http://creativecommons.org/licenses/by/4.0/

c) (i) Open Access

\begin{abstract}
The present research focuses on the Public Forest Service's accountability practices. The Public Forest Service in Greece is used as a research case. This organization produces annually an "Activity Report" based on lagging indicators, presenting to the public past activities in order to manage forest and natural resources in Greece. However, there is no information about negative impacts, no target setting and no indication about sustainability reporting practices. Therefore, the factors that could push the Public Forest Service in Greece to improve its sustainability reporting are explored. Discussions with the expert foresters who are responsible for the data collection and construction of the organization's Activity Report take place for finding out the drivers and barriers of improving such a report to a sustainability report. The results show that the determinants can be divided into internal and external and that in the current framework it will be very difficult for the organization to use methods and indicators that could increase its accountability and sustainability reporting practices.
\end{abstract}

\section{Keywords}

Public Sector Sustainability Reporting, Accountability, Forest Service, Material Flow Cost Accounting, Greece

\section{Introduction}

This paper researches the determinant factors which can lead Public Forest Service in Greece to make the transition from simply publishing an Activity Report to produce and disclose a Sustainability Report for the augmentation of its accountability. Public Sector Sustainability Reporting has been discussed a lot in the literature [1], but no research has been found either for the Greek public sector or for a specialized sector like the Public Forest Service. Generally, in Greece sustainability reporting is an unsystematic and mostly voluntary activity [2]. 
The compliance for reporting is demanded regularly by environmental management systems such as Eco-Management and Audit Scheme and the organizations report the minimum required information [3]. They mostly report on positive impacts and avoid the "hard facts" of social and environmental reporting [2]. They usually use the GRI guidelines as no guidelines have ever been formed by the Government [3].

No reporting guidelines in Greece have also been formed for the public sector organizations. The few public organizations that report on something are municipalities or administrative regions, and united sectors like the Public Forest Service [4]. All these organizations usually report on their public expenditure, an "initiative-focused" reporting; municipalities and administrative regions report on expenditure and actions for the environment, social policy, education and culture, while forest service on its expenditure for the sustainable management and protection of forest resources [5]. Forest Service's Activity Report has been one of the first produced since almost two decades ago.

Forest service has some distinct characteristics compared to other public agencies. Forest service works for the provision of critically important environmental products and services such as biodiversity conservation, oxygen, wood, quarry species, carbon sequestration, and protection from floods among others. It manages a big share of natural capital, such as forests and forest land. Therefore, it does not only need to provide its environmental products, which sometimes other sectors' organizations may use as procurement to improve their environmental performance (for example, wood from sustainably managed forests), but it should produce these products and services in a sustainable way [6]. Generally, organizations with an environmental mandate, like the Forest Service, are expected to perform better compared to other organizations [7].

Due to the reason that the Public Forest Service in Greece is a pioneer in producing Activity reports, in this paper it is explored the following research question: what are the drivers and the barriers that can push or hinder this public organization to move forward and produce the first sustainability report in Greece by such a public organization? For the objective of the research qualitative discussions with Public Forest Service managers (foresters) took place.

\section{Public Sector Sustainability Accounting and Reporting}

Environmental performance of private sector organizations has been thoroughly explored in the literature the last three decades [8]. Several developed countries recognized the impacts of industries and corporations production process to the natural environment and put pressures for increasing their environmental behavior. They also asked for a transparent transition to such a performance by pressing private sector to report on its environmental activities [9]. However, the linear correlation of environmental performance and environmental reporting was not always positive [10] [11].

The introduction of Global Reporting Initiative's Guidelines for Environmental Reporting was a first step for the transition from just paying attention to the environment to a more sustainable operation [12]. Now, the private sector is pressured to integrate the social, environmental and economic aspect of sustainability, improve its performance, implement sustainability management control systems, and report on its activities [13]-[15].

The public and non-governmental sectors were later affected by the above pressures, too [16] [17]. The calls for an improvement in their sustainability performance and reporting were not as many as in the private sector, although their cumulative impact is as likely important [18]. There are some scholars who believe that these sectors are those who have to lead by example [19]. They may also discriminate the agencies with environmental mandate compared to other public agencies [7].

The term of sustainability accounting has been introduced in the literature for more than ten years now [20]. It is a term which gradually replaced and put under its "umbrella" the terms of social and environmental accounting, triple-bottom line accounting and other relevant terms [21]. Researchers have tried to find out what this term includes in general and specifically, and define it [20] [21]. However, corporate practice has shown that it can be used with different meanings, from a "buzzword" to a "pragmatic goal driven set of tools" [21]. The goal driven interpretation of sustainability accounting is the integrated approach to sustainable issues, which not only is relevant to legislative and stakeholder pressure, but it is also driven by ethical reasons [21].

This approach seems to be the one that best fits the public sector as being concerned with promoting values such as public good, social justice and sustainable communities, so it can lead by example in promoting sustainability accounting [22] [23]. Some of the reasons why GRI produced the pilot version of public sector's guidelines [24] were the fact that it could promote transparency and accountability in the sector, and that it has a ma- 
jor impact on national and global progress towards sustainable development [25]. However, some critic says that such guidelines for public and third sector organizations usually do not contribute to sustainability [17] since they have a managerialist approach to it, rather than an ecological approach [17] [26]. On the other hand, these guidelines can help managers within such organizations realize the "full" picture of their operation and improve their decision making for the benefit of environment and society [1] [19] [27]. Specific guidelines for public sector sustainability accounting have been issued only by GRI [24], while more general guidelines that can be used both by corporate or public organizations have been issued by GRI, Account Ability framework, United Nations Global Compact and other organizations [28].

Sustainability accounting for public sector has been mainly examined through the reporting dimension. The majority of research has focused on the drivers that push public sector to report on sustainability issues, and the aspects covered by public sector's sustainability reports [1] [29] [30]. Reference [31] found that public authorities' environmental reporting disclosure was positively related to the development of environmental management systems within these organizations. Recently it was found that the reporting activities of some public sector agencies have been reduced in the last years [32] [33], but there are still some new trends by the sector, like reporting on biodiversity issues, though not very encouraging [34].

The reasons why some public organizations measure and disclose sustainability issues seem to be no mandatory. Reference [1] found that Australian public sector reports on a voluntary basis and due to some key persons within the organization who took the initiative to produce such reports. Their objective is to inform mostly the internal organizations about sustainability issues. Generally, Australia and New Zealand have favored public agency sustainability reporting due to the existence of the Centre for Public Agency Sustainability Reporting that helped public organizations adopt such a policy [35]. The issues that are measured and discussed in the reports of the Australian agencies are mostly non-monetary and declarative, while they are mostly oriented on labor practices and decent work [30]. Reference [36] confirms that local councils in Australian coastal regions provide low disclosures for their environmental expenditures, and finds high disclosures on water and biodiversity issues. Reference [37] finds the social aspect of sustainability reporting to be favored among local government sector authorities in Australia; sustainability information is less and is some way off, but there is some room for improvement, according to the researchers. Reference [38] finds that local public councils, which are the closest administrative unit to citizens, may play a significant role in promoting sustainability and that stakeholder engagement in the production of these councils' sustainability reports is a key issue for this objective.

In New Zealand [39] find that local government sustainability reporting is not prompted by an idealistic desire to help on the way to a sustainable world, but by more managerial reasons like leadership, accountability and financial incentives. When it comes to biodiversity reporting in New Zealand public authorities, [40] finds that regional and unitary authorities are more likely to report on biodiversity issues compared to territorial authorities, and that the quantity and quality of information is not guided by an institutional framework. In Spain [41] find that social and environmental information on the reports of Spanish municipalities is very rare, especially compared to financial information and it may be influenced negatively by the presence of conservative political parties in the government. For the same country [42] and [43] find that the quantity of sustainability information in regional governments' reports is dependent on socio-economic factors such as population density and level of education, and on e-government factors such as broadband availability. Legitimacy and accountability reasons are the motivations for sustainability reporting in Italian local councils [44]. New trends in public sector reporting like climate change (carbon) and biodiversity reporting show that public organizations do not report sufficient information about these issues [34] [45].

From this literature review, Table 1 can be extracted, which shows the determinants for sustainability reporting in public organizations, and the content of the respective reports.

\section{Methodology}

The research method was the following: for finding out the current reporting practices of Public Forest Service in Greece, its annual report was used as case study [4]. The organization issues an annual Activity Report informing stakeholders generally about its actions for forests in whole Greece and the financial resources spent or invested for these actions. The 2010 report was checked in terms of the sustainability information content included. Additionally, two qualitative discussions (with open questions) took place in the central offices of the organization with two foresters-managers. The one interview took place with the expert forester (First Expert) 
Table 1. Determinants for sustainability reporting and its content in public organizations.

\begin{tabular}{cc}
\hline & Public Sector Sustainability Reporting \\
\hline Determinants & Content \\
\hline No mandatory (voluntary) & $\begin{array}{c}\text { Non-monetary information } \\
\text { Key persons' initiative } \\
\text { Internal information } \\
\text { Managerial instead of sustainability reasons } \\
\text { Guided by voluntary and not institutional frameworks } \\
\text { Legitimacy and accountability reasons } \\
\text { Low disclosure on environmental expenditure } \\
\text { Not sufficient information on environmental, biodiversity, and } \\
\text { climate change issues }\end{array}$ \\
\hline
\end{tabular}

who is responsible for the data collection and, who voluntarily some years ago decided to construct the Forest Service Activity Report.

The second discussion took place with the forester-director (Second Expert) of the new Department of Forest Statistics which resumed in late 2014. Generally, a research interviewing experts is common in social and economic sciences [46], and is used when specialized information has to be obtained [47]. However, for such research a minimum of 6 to 12 experts is the optimum number [48]. In this research two experts were available, however it is believed that their experience gives a clear picture for the drivers and barriers of sustainability reporting in Public Forest Service in Greece, as they are presented in the results section.

\section{Results}

\subsection{Contents of Activity Report and Sustainability Information}

As it is expected from an organization working for an environmental sector like forestry, the content includes enough business-as-usual environmental information. The report presents 27 tables with information about expenses for forestry works such as timber production, forest roads, seedlings production, hunting-fishing, reforestation and afforestation, National Parks, grasslands, forest conservation, and supervision of private forestry. Information is also given about quantities of seedlings produced, hunting licenses sold, grassland improvement, CITES convention licenses sold, area in hectares of reforested or afforested land, forest fires and hectares of burned forest land. The information given is mostly in numbers. There is no target set, no benchmarks, and no explanation why, for example, seedlings production has been reduced from 5.5 in 2009 to 4.9 in 2010 million trees. Although sustainable forest management is described as one of the main principles of Greek forestry, no hectare of Greek forests is certified by a certification scheme (for example, Forest Stewardship Council or Sustainable Forest Initiative) for its sustainability. No information is given about the negative environmental impacts of the production process of the organization, such as that of timber production, or positive environmental impacts of reforestation (for example, $\mathrm{CO}_{2}$ sequestration). No information is given about social impacts, such as accidents of forest works, or positive social impacts, such as occupation of mountainous people in forest works. The report seems to be mainly an initiative focused reporting, including "light" information, and no "hard facts".

Sustainability information is practically non-existent in this Activity Report. Although, for instance, sustainable forest management is described as one of the main principles of Greek forestry, it is not apparent that it is achieved. In our question to the two experts if the Forest Service in Greece manages its forests sustainably, the foresters answered in an affirmative manner. However, they admitted that this is not shown clearly in the report. The first expert explained that it is difficult to prove something like that when there is not a new account of the National Forest Capital. The last national forest inventory in Greece took place in 1992. In order to include more sustainability information in the current report a change in the structure of Forest Service has to take place according to the forester. The current structure does not allow someone to work only on collecting the data and forming sustainability reporting indicators. The second expert explained that the personnel is rather old now and due to the financial crisis in Greece, no new personnel is hired to work on such issues.

The first expert was not aware either of the GRI's sustainability indicators (including the indicators for public agencies [24]) or Global Compact's ones. When they were presented to him, he said that some information can 
be disclosed directly if someone decides to follow GRI's structure for the presentation of the report. For other indicators, though not very hard to disclose, much work has to be done to organize the regional forest offices to send this kind of information. He mentioned that sometimes it is impossible to collect some data from the regional forest offices for the current indicators that are used in the Activity Report. If new indicators are to be demanded then he disputes that the central offices could ever collect a representative sample from the regional offices.

Compared to findings about reporting content in Table 1, there is an inverted situation; there is enough environmental information and its expenditure, and no social information; however, the environmental information is the business-as-usual picture of the organization, and not sustainability-driven information.

\subsection{Drivers for Reporting}

In our question to the First Expert for which the main drivers were so that the Forest Service initiated a report at first place, the answer was that voluntary reasons were mostly the case. The forest statistics department collects information about the indicators mentioned above. This information is obligatory to be sent by the regional forest offices (in total 103), which operate all over Greece, to the central Forest Service in Athens. So, when the current forester was moved in the department, he decided to form a report which mainly consisted of tables and figures.

There were no institutional pressures to initiate such a report, or pressures by other stakeholders. At first, this report was not published to the general public. It was sent to the Prime Minister and the Ministers of Environment and Agriculture so that they get informed about the annual activities of Public Forest Service. It was also sent to other public agencies and the regional forest offices in Greece. By forming this report and sending it to the Government, the Forest Service tried to make them aware of its existence, strengthen its position compared to other agencies, and secure its government funding, which is usually very parsimonious for the forest sector. So, this is an indication that the organization tried to manage its reputation by reporting. From 2002 the Activity Report started being published on the internet.

However, this report is based only on lagging indicators, it reports no goals, no strategy, or whether the targets were achieved during the reporting period or not. The forester mentioned that it plays little role in the management decisions of the agency, but this is the only way to form the report. Compared to Table 1 findings about reporting, the literature is confirmed in how a public organization initiates a non-mandatory report; the reporting activity in the Greek Public Forest Service started due to the voluntary will of a key person in the organization, and it was used for managerial reasons, for securing the Government funding. By this one could argue that voluntary disclosure provides reputation benefits even though stakeholders don't make pressures for having access to that information.

\subsection{Drivers and Barriers for Sustainability Reporting}

The first expert was questioned if the Forest Service estimates its negative environmental impact by using methods like Material Flow Cost Accounting (for example in order to estimate the cost of the non-product outputs resulting from the operation either of the offices or from the work in forests during the wood production process, or the operation of public farms) [6]. The answer was negative. He could understand the environmental impact of the wood production process, but he seemed unaware that the impact of the office operation can be translated into a non-product output. He also seemed not to have thought the fact that some of the forest service's activities have positive externalities for the society, for example afforestation of non-forested areas through carbon sequestration, and the missing opportunity of the organization to present a positive image to the public. Additionally, he mentioned that he was unaware of methods like Material Flow Cost Accounting, especially because of the fact that such methods are new and coming from other scientific disciplines. He believed that new personnel have to enter in the organization with knowledge about such methodologies and desire to work on such issues.

In the question about which factors may affect the integration of sustainability performance measurement and leading indicators in the existing reporting scheme, he answered that he did not expect pressures from the government. He did not believe either in a Greek legislation change about reporting of public agencies. However, he believed that the Forest Service should indeed try to increase its sustainability performance measurement, set a number of leading indicators and generally change its strategy, because he felt that, when initiatives like GRI exist in voluntary terms, it will not take long to become mandatory; especially, as Greece is a member of the 
European Union and much of its sustainability legislation comes after compliance with EU law. Thus, the Forest Service should be ready to comply with such a situation in the future.

Finally, he felt that education on sustainability accounting and reporting was missing for the foresters in this agency. He was unaware of most of methodologies discussed and no one had educated him or other members of the Forest Service for such issues. He believed that in the current structure of the forest agency it seemed very difficult that someone could have the time and the desire to take the initiative and try to apply methodologies like Material Flow Cost Accounting and Sustainability Reporting.

The Second Expert believed that there should take place an effective re-organization of where the current personnel work. He admitted that the resumed forest statistics department lacks of educated in statistics personnel, and that few old people working there are almost unaware of handling computer software. He confirmed that the current personnel in Forest Service is not in favor of learning and applying new methodologies, and this will get worse as many people retire and no new personnel is added. The remaining personnel are so over-occupied with the current duties that adding new duties to them would simply produce no result.

\section{Discussion}

As an organization with an environmental mandate, Greek Public Forest Service's Reporting on sustainability issues would augment its accountability. As a public agency, this organization has many stakeholders who are interested in its operation, though they do not demand it. The organization should form a number of suitable indicators for monitoring its impacts, should set some targets, and explain each year why these targets have been met or not. Examples of possible indicators could be the energy spent for $1 \mathrm{~m}^{3}$ of wood product, or the percentage of hunted species which come from releases to the total number of released species [6]. Of course, the organization could also report on positive environmental impacts that occur from the $\mathrm{CO}_{2}$ sequestration as a result of the forest management practices and the reforestations or afforestations.

For implementing all these, however, it is confirmed firstly that both internal and external factors affect the situation of sustainability reporting either by driving it or by hindering it, as other similar research have revealed [49]. Determinants such as reputation of the organization stimulate at first the existence of the reporting practices in Greek Forest Service. This is an internal pressure which drives the production of the annual report. This may be a novel finding for this research field, since even though stakeholders do not demand the publication of the report, the organization earns reputation benefits. On the other hand, internal reasons such as the structure of the organization hinders the quality of the report, its speed of publication, and the inclusion of more sustainability information confirming previous researchers [6] [19] [50] who assume that a systematic and reliable data collection and analysis department is a prerequisite for sustainability management.

Education seems to be a factor which hinders the implementation of sustainability accounting methods, like material flow cost accounting, and the integration of such indicators into sustainability reporting. The foresters-managers of the Greek Forest Service are unaware of GRI indicators or Environmental Management Accounting methods. Additionally, the current structure of the organization with its employees getting older, without new foresters to be employed (due to the Greek economic downturn the last years) makes it difficult to change the business-as-usual situation. The fact, also, that, according to the Activity Report, in the Greek Forest Service mainly foresters are employed, while in other countries such as United States they consist only the 30\% of the personnel [51], is an indicator that it is difficult for interdisciplinary issues to emerge in the service and it can be assumed reasonable that sustainability reporting and performance measurement are not in the high list of priorities for the sector.

On the other hand, the cost reduction offered by methods such as Material Flow Cost Accounting seems to be a driver for the inclusion of such practices in the everyday work of the agency. Additionally, the compliance with future regulation seems that can put pressure on the existent personnel to try and integrate some of the knowledge obtained after the interview.

Table 2 summarizes the drivers and barriers of sustainability reporting in the Public Forest Service in Greece, which are divided into internal and external.

\section{Conclusions}

The present research tried to understand the determinant factors that might affect the inclusion of sustainability 
Table 2. Determinants for sustainability reporting in the public forest service in Greece.

\begin{tabular}{|c|c|c|c|}
\hline \multicolumn{2}{|c|}{ Drivers } & \multicolumn{2}{|c|}{ Barriers } \\
\hline Internal & External & Internal & External \\
\hline Voluntary work & $\begin{array}{l}\text { Compliance with future EU } \\
\text { environmental legislation }\end{array}$ & Current structure of the organization & No stakeholders’ pressures \\
\hline Key person initiative & & Aged personnel & No legislation about reporting \\
\hline Managerial reasons & & $\begin{array}{l}\text { Personnel consisting only } \\
\text { from foresters }\end{array}$ & \\
\hline Reputation & & Lack of education and time & \\
\hline Cost reduction & & $\begin{array}{c}\text { Not suitable personnel in the statistics } \\
\text { department }\end{array}$ & \\
\hline
\end{tabular}

information in the current reporting system of the Greek Public Forest Service. It occurred because of the authors' belief that public sector organizations with an environmental mandate should lead by example in sustainability issues and have a transparent and accountable operation. Especially, the Forest Service which is the first that used the word and the substance of sustainability in its work [52].

The drivers and barriers for this to happen can be divided into internal and external. The internal drivers include the voluntary work of one forester working in a department which is not obliged to produce annual reports; additionally, the need for enhancing the organization's reputation into the society but especially into the Government organizations, which may secure its funding and its existence; finally, cost reduction issues occurring from the application of methods such as Material Flow Cost Accounting. The internal barriers are related to the current structure of the organization, where there are difficulties in the collection and analysis of sustainability information; the personnel, additionally, is getting older with limited desire to change the business-as-usual work; and finally, there is a lack of education to the foresters to administrate such work, together with a lack of an interdisciplinary personnel. The external driver is mainly a possible future need to comply with new environmental laws that will make sustainability performance and reporting mandatory. External barriers are relevant to the fact that there is no institutional pressure for the public sector to report on sustainability issues.

Further research is needed for finding out if Forest Service in other countries produces sustainability reports and the factors that affect such practices.

\section{Acknowledgements}

In the memory of Professor Athanassios Christodoulou who passed away during the research. The first author would like to thank the IKY Fellowships of Excellence for Postgraduate Studies in Greece-Siemens Program for funding him for this research. The first author would like to thank the AUTh Research Committee-Special Account for Research Funds for a post-doctoral scholarship in 2012, which helped him in a small part of the above research.

\section{References}

[1] Farneti, F. and Guthrie, J. (2009) Sustainability Reporting by Australian Public Sector Organisations: Why They Report. Accounting Forum, 33, 89-98. http://dx.doi.org/10.1016/j.accfor.2009.04.002

[2] Evangelinos, K.I. and Skouloudis, A. (2014) European Perspectives on Corporate Non-Financial Disclosure: Evidence from the Southeast. International Journal of Disclosure and Governance, 11, 33-53. http://dx.doi.org/10.1057/jdg.2012.13

[3] Papaspyropoulos, K.G., Blioumis, V. and Christodoulou, A.S. (2010) Environmental Reporting in Greece: The Athens Stock Exchange. African Journal of Business Management, 4, 2693-2704.

[4] Greek Ministry of Environment and Energy (2012) Activity Report of Public Forest Services for 2010. Athens. (In Greek)

[5] Papaspyropoulos, K.G. (2013) From Initiative Focused Reporting to Sustainability Reporting: A Step forward for a More Accountable Forest Service. AUTh, Thessaloniki. (In Greek)

[6] Papaspyropoulos, K.G., Karamanolis, D., Sokos, C.K. and Birtsas, P.K. (2016) Enhancing Sustainability in Forestry 
Using Material Flow Cost Accounting. Open Journal of Forestry. (In Press)

[7] Lodhia, S., Jacobs, K. and Park, Y.J. (2012) Driving Public Sector Environmental Reporting: The Disclosure Practices of Australian Commonwealth Departments. Public Management Review, 14, 631-647. http://dx.doi.org/10.1080/14719037.2011.642565

[8] Schaltegger, S. and Synnestvedt, T. (2002) The Link between “Green” and Economic Success: Environmental Management as the Crucial Trigger between Environmental and Economic Performance. Journal of Environmental Management, 65, 339-346.

[9] Wiseman, J. (1982) An Evaluation of Environmental Disclosures Made in Corporate Annual Reports. Accounting, Organizations and Society, 7, 53-63. http://dx.doi.org/10.1016/0361-3682(82)90025-3

[10] Al-Tuwaijri, S.A., Christensen, T.E. and Hughes II, K.E. (2004) The Relations among Environmental Disclosure, Environmental Performance, and Economic Performance: A Simultaneous Equations Approach. Accounting, Organizations and Society, 29, 447-471. http://dx.doi.org/10.1016/S0361-3682(03)00032-1

[11] Clarkson, P.M., Li, Y., Richardson, G.D. and Vasvari, F.P. (2008) Revisiting the Relation between Environmental Performance and Environmental Disclosure: An Empirical Analysis. Accounting, Organizations and Society, 33, 303327. http://dx.doi.org/10.1016/j.aos.2007.05.003

[12] Brown, H.S., de Jong, M. and Levy, D.L. (2009) Building Institutions Based on Information Disclosure: Lessons from GRI’s Sustainability Reporting. Journal of Cleaner Production, 17, 571-580. http://dx.doi.org/10.1016/j.jclepro.2008.12.009

[13] Schaltegger, S. and Wagner, M. (2006) Integrative Management of Sustainability Performance, Measurement and Reporting. International Journal of Accounting, Auditing and Performance Evaluation, 3, 1-19. http://dx.doi.org/10.1504/IJAAPE.2006.010098

[14] Maas, K., Schaltegger, S. and Crutzen, N. (2016) Advancing the Integration of Corporate Sustainability Measurement, Management and Reporting. Journal of Cleaner Production, 133, 859-862. http://dx.doi.org/10.1016/j.jclepro.2016.06.006

[15] Maas, K., Schaltegger, S. and Crutzen, N. (2016) Integrating Corporate Sustainability Assessment, Management Accounting, Control, and Reporting. Journal of Cleaner Production. (In Press)

[16] Adams, C.A., Muir, S. and Hoque, Z. (2014) Measurement of Sustainability Performance in the Public Sector. Sustainability Accounting, Management and Policy Journal, 5, 46-67. http://dx.doi.org/10.1108/SAMPJ-04-2012-0018

[17] Dumay, J., Guthrie, J. and Farneti, F. (2010) GRI Sustainability Reporting Guidelines for Public and Third Sector Organizations: A Critical Review. Public Management Review, 12, 531-548. http://dx.doi.org/10.1080/14719037.2010.496266

[18] Dart, R. and Hill, S.D. (2010) Green matters? An Exploration of Environmental Performance in the Nonprofit Sector. Nonprofit Management and Leadership, 20, 295-314. http://dx.doi.org/10.1002/nml.255

[19] Papaspyropoulos, K.G., Blioumis, V., Christodoulou, A.S., Birtsas, P.K. and Skordas, K.E. (2012) Challenges in Implementing Environmental Management Accounting Tools: The Case of a Nonprofit Forestry Organization. Journal of Cleaner Production, 29-30, 132-143. http://dx.doi.org/10.1016/j.jclepro.2012.02.004

[20] Lamberton, G. (2005) Sustainability Accounting: A Brief History and Conceptual Framework. Accounting Forum, 29, 7-26. http://dx.doi.org/10.1016/j.accfor.2004.11.001

[21] Schaltegger, S. and Burritt, R.L. (2011) Sustainability Accounting for Companies: Catchphrase or Decision Support for Business Leaders? Journal of World Business, 45, 375-384. http://dx.doi.org/10.1016/j.jwb.2009.08.002

[22] Ball, A. and Bebbington, J. (2008) Editorial: Accounting and Reporting for Sustainable Development in Public Service Organizations. Public Money and Management, 28, 323-326. http://dx.doi.org/10.1111/j.1467-9302.2008.00662.x

[23] Ball, A., Mason, I., Grubnic, S. and Hughes, P. (2009) The Carbon Neutral Public Sector. Public Management Review, 11, 575-600. http://dx.doi.org/10.1080/14719030902798263

[24] Global Reporting Initiative (GRI) (2005) Sector Supplement for Public Agencies. With an abridged version of the GRI 2002 Sustainability Reporting Guidelines.

[25] Guthrie, J., Ball, A. and Farneti, F. (2010) Advancing Sustainable Management of Public and Not for Profit Organizations. Public Management Review, 12, 449-459. http://dx.doi.org/10.1080/14719037.2010.496254

[26] Gray, R. (2006) Social, Environmental and Sustainability Reporting and Organisational Value Creation? Whose Value? Whose Creation? Accounting, Auditing and Accountability Journal, 19, 793-819. http://dx.doi.org/10.1108/09513570610709872

[27] Farneti, F. and Siboni, B. (2011) An Analysis of the Italian Governmental Guidelines and of the Local Governments' Practices for Social Reports. Sustainability Accounting, Management and Policy Journal, 2, 101-125. http://dx.doi.org/10.1108/20408021111162146 
[28] Marx, B. and van Dyk, V. (2011) Sustainability Reporting at Large Public Sector Entities in South Africa. South African Journal of Accounting Research, 25, 103-127. http://dx.doi.org/10.1080/10291954.2011.11435155

[29] Burritt, R.L. and Welch, S. (1997) Accountability for Environmental Performance of the Australian Commonwealth Public Sector. Accounting, Auditing and Accountability Journal, 10, 532-561. http://dx.doi.org/10.1108/09513579710367494

[30] Guthrie, J. and Farneti, F. (2008) GRI Sustainability Reporting by Australian Public Sector Organizations. Public Money and Management, 28, 361-366. http://dx.doi.org/10.1111/j.1467-9302.2008.00670.x

[31] Frost, G.R. and Seamer, M. (2002) Adoption of Environmental Reporting and Management Practices: An Analysis of New South Wales Public Sector Entities. Financial accountability and management, 18, 103-127. http://dx.doi.org/10.1111/1468-0408.00147

[32] Bracci, E. and Tallaki, M. (2013) Socio-Environmental Reporting Trends in the Italian Local Government: Thrive or Wither? Financial Reporting, 2, 27-46. http://dx.doi.org/10.3280/FR2013-002003

[33] Vinnari, E. and Laine, M. (2013) Just a Passing Fad?: The Diffusion and Decline of Environmental Reporting in the Finnish Water Sector. Accounting, Auditing and Accountability Journal, 26, 1107-1134. http://dx.doi.org/10.1108/AAAJ-04-2012-01002

[34] Barut, M., Raar, J. and Azim, M.I. (2016) Biodiversity and Local Government: A Reporting and Accountability Perspective. Managerial Auditing Journal, 31, 197-227. http://dx.doi.org/10.1108/MAJ-08-2014-1082

[35] Lamprinidi, S. and Kubo, N. (2008) Debate: The Global Reporting Initiative and Public Agencies. Public Money and Management, 28, 326-329. http://dx.doi.org/10.1111/j.1467-9302.2008.00663.x

[36] Sciulli, N. (2009) Sustainability Reporting by Local Councils in Coastal Regions: An Australian Study. Asian Journal of Finance and Accounting, 1, 76-86. http://dx.doi.org/10.5296/ajfa.v1i1.166

[37] Williams, B., Wilmshurst, T. and Clift, R. (2011) Sustainability Reporting by Local Government in Australia: Current and Future Prospects. Accounting Forum, 35, 176-186. http://dx.doi.org/10.1016/j.accfor.2011.06.004

[38] Kaur, A. and Lodhia, S. (2014) The State of Disclosures on Stakeholder Engagement in Sustainability Reporting in Australian Local Councils. Pacific Accounting Review, 26, 54-74. http://dx.doi.org/10.1108/PAR-07-2013-0064

[39] Bellringer, A., Ball, A. and Craig, R. (2011) Reasons for Sustainability Reporting by New Zealand Local Governments. Sustainability Accounting, Management and Policy Journal, 2, 126-138. http://dx.doi.org/10.1108/20408021111162155

[40] Schneider, A., Samkin, G. and Davey, H. (2014) Biodiversity Reporting by New Zealand Local Authorities: The Current State of Play. Sustainability Accounting, Management and Policy Journal, 5, 425-456. http://dx.doi.org/10.1108/SAMPJ-10-2013-0043

[41] García-Sánchez, I.M., Frías-Aceituno, J.V. and Rodríguez-Domínguez, L. (2013) Determinants of Corporate Social Disclosure in Spanish Local Governments. Journal of Cleaner Production, 39, 60-72. http://dx.doi.org/10.1016/j.jclepro.2012.08.037

[42] Alcaraz-Quiles, F.J., Navarro-Galera, A. and Ortiz-Rodríguez, D. (2014) Factors Influencing the Transparency of Sustainability Information in Regional Governments: An Empirical Study. Journal of Cleaner Production, 82, 179-191. http://dx.doi.org/10.1016/j.jclepro.2014.06.086

[43] Navarro-Galera, A., Alcaraz-Quiles, F. J. and Ortiz-Rodríguez, D. (2016) Online Dissemination of Information on Sustainability in Regional Governments. Effects of Technological Factors. Government Information Quarterly, 33, 5366. http://dx.doi.org/10.1016/j.giq.2015.12.003

[44] Greco, G., Sciulli, N. and D’Onza, G. (2015) The Influence of Stakeholder Engagement on Sustainability Reporting: Evidence from Italian Local Councils. Public Management Review, 17, 465-488. http://dx.doi.org/10.1080/14719037.2013.798024

[45] Liu, Z., Abhayawansa, S., Jubb, C. and Perera, L. (2016) Voluntary Climate Change-Related Reporting of Australian Government-Owned Corporations: The Impact of the National Greenhouse and Energy Reporting Act 2007. 39th Annual Congress of the European Accounting Association, Maastricht, 11-13 May 2016. http://www.eaacongress.org/userfiles/GMFMDJK_FIFKHK_AF1RQ1GR.pdf

[46] Burritt, R. L., Schaltegger, S. and Zvezdov, D. (2011) Carbon Management Accounting: Explaining Practice in Leading German Companies. Australian Accounting Review, 21, 80-98. http://dx.doi.org/10.1111/j.1835-2561.2010.00121.x

[47] Johnson, B. and Turner, L.A. (2003) Data Collection Strategies in Mixed Methods Research. In: Tashakkori, A.M. and Teddlie, C.B., Eds., Handbook of Mixed Methods in Social and Behavioral Research, SAGE Publications, Thousand Oaks, 297-319.

[48] Guest, G., Bunce, A. and Johnson, L. (2006) How Many Interviews Are Enough? An Experiment with Data Saturation 
and Variability. Field methods, 18, 59-82. http://dx.doi.org/10.1177/1525822X05279903

[49] Walker, H., Di Sisto, L. and McBain, D. (2008) Drivers and Barriers to Environmental Supply Chain Management Practices: Lessons from the Public and Private Sectors. Journal of Purchasing and Supply Management, 14, 69-85. http://dx.doi.org/10.1016/j.pursup.2008.01.007

[50] Jasch, C.H. (2009) Environmental and Material Flow Cost Accounting: Principles and Procedures. Springer, Berlin.

[51] Koontz, T.M. (2007) Federal and State Public Forest Administration in the New Millennium: Revisiting Herbert Kaufman’s the Forest Ranger. Public Administration Review, 67, 152-164. http://dx.doi.org/10.1111/j.1540-6210.2006.00704.x

[52] Stamou, N.I. (2006) Economics of Natural Resources and Environment. Aristotle University of Thessaloniki, Thessaloniki. (In Greek)

\section{Submit or recommend next manuscript to SCIRP and we will provide best service for you:}

Accepting pre-submission inquiries through Email, Facebook, LinkedIn, Twitter, etc.

A wide selection of journals (inclusive of 9 subjects, more than 200 journals)

Providing 24-hour high-quality service

User-friendly online submission system

Fair and swift peer-review system

Efficient typesetting and proofreading procedure

Display of the result of downloads and visits, as well as the number of cited articles

Maximum dissemination of your research work

Submit your manuscript at: http://papersubmission.scirp.org/ 